\title{
Review of Evolution for Everyone: How Darwin's Theory Can Change the Way We Think About Our Lives, by David Sloan Wilson
}

\author{
Delacorte Press, 2007, 390 pages
}

\section{Michael Hammond}

Published online: 17 January 2008

(C) Springer Science + Business Media, LLC 2007

Keywords Human evolution · Group selection · Religion

Evolution for Everyone is really two books in one. The first is a delight. The second is more problematical. There is a wonderful introduction to the most basic concepts of modern evolutionary theory. With infectious enthusiasm and excellent examples, Wilson takes the reader through the world of variation, selection, adaptation, interaction effects of genes and the environment, and a host of related concepts. There are also some great metaphors, such as dancing with ghosts to describe what happens when useful adaptations in a past environment become mismatched with the current environment and lead individuals into behaviors with negative impacts. Similarly, there are enchanting chapters on the evolution of laughter, aesthetics, eye contact, and a host of other topics. These sections are truly for everyone. The writing is not condescending in the slightest, and it is not forged in a scientific jargon that might discourage many readers from delving any further into the evolutionist world. In particular, anyone teaching evolution is going to find something of value in these sections.

Mixed in throughout this introduction to evolution are personal stories, sometimes about the author and sometimes about all the other individuals he has crossed paths with in his career. It is possible that some readers might be a little put off by these anecdotes, especially the very personal and occa-

\section{Hammond $(\bowtie)$}

Sociology, University of Toronto,

725 Spadina Avenue,

Toronto, Ontario M5S 2J4, Canada

e-mail: michaelhammond@rogers.com sionally uncomfortable details about individual relationships or about behavior in the scientific community. Failed love, professional competition, concerns about getting to the right graduate school or the right academic position, all are here and right out front. I find this very refreshing, if only because standard scientific writing so ruthlessly excludes these materials. Wilson wants the general reader to understand that evolutionists are not cold-blooded thinking machines, even though they often write as if that were the case. Once again, anyone teaching evolution and hoping to encourage students to pursue further studies in this area should have their students read this book to get some idea about the day-to-day lives of scientists.

Now to some problems in this book. Wilson is a leading advocate of a special kind of multi-level selection theory. From his perspective, evolution occurs not just through individual selection or kin selection but sometimes through group selection where, in his terms, groups function as organisms rather than as groups of organisms. Under certain conditions, this makes it possible for the evolutionary dynamics of groups to trump the evolutionary dynamics of the individuals who make up the groups. This review is not the place to discuss the pros and cons of group-selection theory for human groups. Suffice it to say that groupselection models of human sociality are highly controversial and that most evolutionists use alternative selection models to account for our sociality. However, it would be hard for the average reader to grasp these facts from Wilson's presentation as he gradually moves from widely accepted evolutionist principles to much more controversial positions on group selection in humans without making it abundantly clear to the general reader that he has entered more highly disputed territory. 
For example, many evolutionists have put forward theories on human altruism and cooperation that use selection models other than group selection. However, these alternatives are not discussed in any detail in comparison to the extended presentation of the groupselection perspective. The overall result is that the current majority position arguing there is little or no group selection in the evolution of human sociality is given minority coverage, and the minority position on group selection is given majority coverage.

Similarly, whatever one thinks about the work of Richard Dawkins, he deserves more than a few passing references in a book for everyone about modern evolutionary thinking. After all, the very popular writings of Dawkins cover many of the same issues and provide a natural contrast to Wilson's model of human evolution. The same is true for the work of Stephen Jay Gould, another highly successful popularizer of evolutionary ideas that contrast with Wilson's. Out of almost 400 pages, Dawkins and Gould each get three short mentions. Wilson also notes that Steven Pinker is one of the biggest scientific celebrities in the current study of human evolution, but Pinker's work, based on other selection models, gets only one short reference.

If the title of the book were Group Selection for Everyone, all of this would not be much of a problem, but that is not the actual title. Of course, sometime in the future, group selection may become the most popular theory among human evolutionists, but until that time, more balance would be best for a general book with the stated goal of introducing evolution to everyone.

I am also somewhat doubtful about Wilson's selflabeled "tall claim" on the very first page that if properly understood, "evolution and religion, those old enemies who currently occupy opposite corners of human thought, can be brought harmoniously together". This potential harmony seems to be based on the idea that, particularly from a group-selection perspective, the benefits of religion on average must outweigh the costs. Otherwise, there would be no selection in favor of the evolution of religion. If evolutionary theory can demonstrate that religion is beneficial over all, then there might exist a common ground with true believers in religion, who from a very different perspective also argue that the benefits of belief outweigh the costs. Wilson is extremely optimistic about this common ground, but I am reminded of many sociologists of religion who had much the same optimism in the late 1980s when they began to apply rational choice models from economics to the study of religion. They too came to the same conclusion. Religions only persist when there are more gains than losses for individuals who embrace the religion. They too thought that finally there was common ground for a rapprochement between social scientists and religious believers. However, there has not been much evidence of this reconciliation over the last two decades, and the same fate could await this second candidate for intellectual harmony. 